\title{
Announcing New Contracts for Clinical Practice Guidelines
}

The Office of the Forum for Quality and Effectiveness in Health Care of the Agency for Health Care Policy and Research (AHCPR) has announced a request for contracts to develop and update clinical practice guidelines, medical review criteria, standards of quality, and performance measures on screening for colorectal cancer, management of chronic pain with special emphasis on headache pain, and nosocomial urinary tract infection (RFP No. 282-93-0029).

A separate contract will be awarded for development of these products for each of the above clinical conditions. Although an offeror may apply for any/all of these contracts, AHCPR intends to award no more than one contract to any offeror.

Anyone interested in applying for a contract should write to DHHS, Public Health Service, Division of Acquisition Management, GAB Branch, Room 5-101, Parklawn Bldg., 5600 Fishers Ln., Rockville, MD 20857, Attn: 5103 PKLN/Michele Trotter; telephone (301) 443-2475, fax (301) 443-3849.

\section{Evaluation of the NNIS}

Between May 1 and June 15, 1993, CDC's procurement and grants office opened an opportunity for interested individuals or organizations to respond to an RFP intended to address the sensitivity and specificity of the nosocomial infection case-finding and resultant data submitted to the National Nosocomial Surveillance System (NNIS) by its member hospitals. CDC intends to provide not only measures for the adjustment of the nosocomial infection rates found at NNIS member hospitals for interhospital comparisons, but also a model for the study of other medical care outcomes. SHEA will follow up on which organizations are chosen to engage in this important work and provide progress reports on it as they become available.

\section{Conference to Be Held on Preventing Transmission of Bloodborne Pathogens in Surgery and Obstetrics}

This conference will be sponsored by the American College of Surgeons and the Centers for Disease Control and Prevention. The conference will take place at the Hilton Hotel in Atlanta, Georgia, on February 13-15, 1994.

This conference will provide information regarding the risk of transmission of bloodborne pathogens, including HIV and hepatitis $\mathrm{B}$ and $\mathrm{C}$ viruses, during surgical and obstetrical procedures and describe methods to reduce that risk. The conference will bring together surgeons, obstetricians, anesthesiologists, surgical and obstetrical nurses and technicians, hospital epidemiologists, and infection control practitioners. The program will include state-of-theart lectures by experts in the field as well as presentations of abstracts of original research. Major topics will include:

- current data relating to the risk of transmission of bloodborne pathogens to healthcare workers and patients in surgical and obstetrical suites,

- information on new devices, techniques, and personal protective equipment that may decrease occupational exposure in surgical and obstetrical suites,

- additional preventive measures, such as immunization and postexposure management, and

- methods to conduct and evaluate studies of risk factors and prevention measures.

Abstracts should be typed on plain white paper, single-spaced, no longer than 250 words, with two-inch top and bottom margins, and $21 / 8$-inch side margins. The abstract should be headed with title, author names with degrees and institution, city and state, with an asterisk next to the presenting author. This will be followed with the objectives, methods, results, and conclusions of the research. Abstracts will be printed exactly as received. Abstract and four copies should be mailed, with presenting author's address and telephone number, to Bloodborne Pathogen Conference, HIV Infections Branch, Hospital Infections Program, Centers for Disease Control and Prevention, Mailstop A-07, Atlanta, GA 30333. Deadline for receiving abstracts is October 31, 1993.

For hotel information and registration forms, contact John P. Lynch, Organization Department, American College of Surgeons, 55 East Erie St., Chicago, IL 60011-2797. Telephone (312) 664-4050.

Brief items of interest for the SHEA N ews or N ewsletter may be sent to C. Glen Mayhall, M D, SHEA, N ewsletter Editor, Division of Infectious D iseases, D epartment of M edicine, U niversity of Tennessee, M emphis, 956 Court A ve., M emphis, TN 38163; FAX (901) 528-5854. Copy should be typed, double-spaced, and should not exceed five pages. 